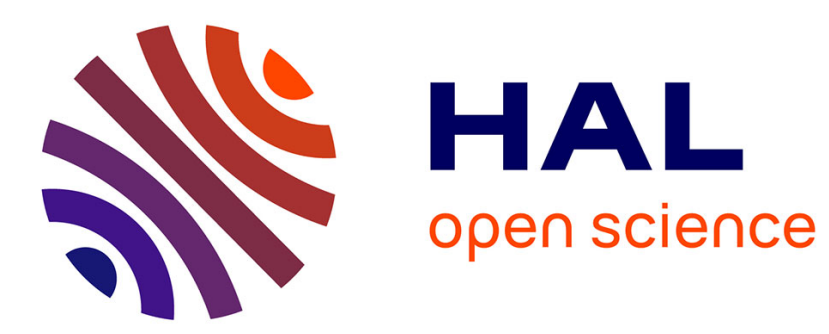

\title{
Defence capability in the UK since 2010: explaining change in procurement practices
}

\author{
Andy Smith, Benoit Giry
}

\section{To cite this version:}

Andy Smith, Benoit Giry. Defence capability in the UK since 2010: explaining change in procurement practices. British Politics, 2019, 15 (4), pp.433-455. 10.1057/s41293-019-00125-4 . halshs-02294025

\section{HAL Id: halshs-02294025 \\ https://shs.hal.science/halshs-02294025}

Submitted on 19 Mar 2020

HAL is a multi-disciplinary open access archive for the deposit and dissemination of scientific research documents, whether they are published or not. The documents may come from teaching and research institutions in France or abroad, or from public or private research centers.
L'archive ouverte pluridisciplinaire HAL, est destinée au dépôt et à la diffusion de documents scientifiques de niveau recherche, publiés ou non, émanant des établissements d'enseignement et de recherche français ou étrangers, des laboratoires publics ou privés. 


\title{
Defence Capability in the UK Since 2010: Explaining Change in
}

\section{Procurement Practices}

\author{
Andy Smith \\ Centre Emile Durkheim \\ Sciences-Po Bordeaux \\ 11 allée Ausone \\ Pessac 33670 \\ a.smith@sciencespobordeaux.fr \\ Benoit Giry \\ ARENE \\ Institute of Political Studies \\ Sciences-Po Rennes \\ 8 Boulevard de la Duchesse Anne \\ 35000 Rennes \\ benoit.giry@sciencespo-rennes.fr
}

\begin{abstract}
:
Arms procurement highlights tensions within British industrial policy. Once seen as an economic sanctuary to be preserved in the name of 'strategy', in the 1980s it became a symbol of neoliberalization. But how can contemporary procurement in the UK be characterized? To answer this question, this article analyses 'political work' carried out by politicians, bureaucrats and military officers within the MoD and DE\&S, the state agency in charge of defence equipment and support since 2006. Beyond the protectionist/liberalised dichotomy, our documentary, interview and lexical analysis reveals the development of a new policy frame we label 'value management'. We first show how the issue of procurement has been reproblematized around the term 'capability' to provide a new set of regulatory organizing principles and social relations. The way in which this frame has been equipped with managerial and policy instruments is then analyzed. Finally, we show how this 'problem' and these instruments have been legitimized in a way that transcends the polar opposites of neo-liberal cost-cutting and interventionist industrial policy. Overall, we conclude that 'value management' is currently proposing the basis for a new British defence consensus.
\end{abstract}

Key words: Defence; procurement; equipment support; industrial policy; neoliberalism 


\section{Introduction}

The procurement of defence equipment is an important yet curious political issue. The subject frequently makes the headlines, notably because of its sheer cost, its links to employment, and the lives of servicemen and women put at risk when it goes wrong. These issues are all the more salient in the United Kingdom (UK) where controversy over the production and acquisition of defence equipment has been frequent since the end of the 'domestic defence consensus' in the 1980s (Dorman, 2002, p. 3). Indeed, over the last four decades this country's relatively large defence equipment budget has been scrutinized vigorously in Parliament, by political parties, interested companies, a wide range of 'experts' and the media. More precisely, as part 1 of this piece briefly recalls, since 1945 the actual availability of British defence equipment has regularly been controversial and often publicly so.

This makes equipment availability highly relevant for the scientific observation of political activity. However, since 2010, the governmental policy upon which such availability largely depends -'equipment support'- have given rise to virtually no academic publications ${ }^{1}$. More perplexingly still, despite the enormous sums of money involved, virtually all the vast literature on arms acquisition pays only lip service to how equipment is maintained and updated once it has been purchased (e.g. Louth \& Taylor, 2016; Moore, 2016). In focusing upon the inextricable link between equipment procurement and support within recent British practice, what we seek to analyse here are the institutionalized arrangements regarding 'equipment support' that have

\footnotetext{
${ }^{1}$ Since 2010, Defence Studies has published 6 articles that touch upon availability, Armed Forces and Society 2, and Defence and Peace Economics 10. However, only one of these pieces addresses the issue of equipment support (Erbel, 2017).
} 
developed between this country's Ministry of Defence (MOD), armed forces and manufacturers, - i.e. the set of actors who ostensibly ensure that each piece of 'kit' is maintained so as to be available and appropriate for use by each service's personnel. We enquire into why these arrangements have changed since the late 2000's and what now characterizes the British model of defence procurement and equipment support?

Specifically, using qualitative and quantitative data from several sources ${ }^{2}$, this article analyses change in the way British defence equipment support has been procured since 2010. Restated in full in part 4, our overall argument, is twofold. Firstly, in terms of what has changed, and thus our dependent variable, we argue that during this period a new approach we label 'value management' has progressively been institutionalized. Crucially, this approach is different from that of either neoliberal cost-cutters, or their direct opponents who champion interventionist defence industrial policy. Secondly, to explain this change the independent variable we propose is the 'political work' (Smith 2016; 2019) conducted by a precise set of political, administrative, 'expert' and military actors. Specifically, as part 2 will argue, frames (Goffman, 1974) have been built containing the codes with which these actors have interpreted the public problem (Gusfield, 1981; Rochefort \& Cobb, 1994) of defence equipment procurement and support. As part 3 highlights, these frames have been defended by these actors in the form of proposals for policy instrumentation (Le Galès \& Lascoumes, 2007) and ethoses (Bourdieu, 2000; Emmerich, 2016). Indeed, the latter condense how each actor

\footnotetext{
${ }^{2}$ Our analysis is based upon a comprehensive literature review, examination of the National Archives in Kew, and a dozen interviews with past and present employees of the Ministry of Defence, experts, the UK Parliament and an exMinister. In addition, we have undertaken computerized content analysis of ministerial speeches (see Box 1 in Section 2).
} 
defines, prioritizes and defends their respective definition of what they consider to be fair and just; what one cares about, what actors count, and also what counts for them.

As part 4's discussion of our results sets out in detail, the central claim derived from this approach to policymaking and our empirical research is as follows: over the 2010s, political work centred upon the term 'capability' has provided certain key actors with a means to reframe the procurement of defence equipment support. During the coalition then Conservative governments in office during this period, this reframing has been institutionalized by developing a hybrid between neo-liberal public management and an interventionist approach to defence industrial policy. Our overall conclusion is that this new frame, which we label 'value management', has recently generated the basis for a new British defence consensus. We argue that this re-institutionalization has been caused by a variety of senior personnel in the civil service and armed forces, together

with at least one minister, developing a new definition of 'the public problem' of equipment support, together with policy instruments and a legitimizing discourse that fit with this reframing of the public policy at issue.

\section{The Place of Equipment as an Issue within British Defence Since 1945}

As Baylis underlines (1989), until the 1980s, change in British procurement had been incremental and relatively depoliticized, i.e. without publicized controversies around publicly defended values or points of principle. Indeed, the concept of a 'defence consensus' was even developed to reflect continuity between Labour and Conservative policies in this area (Jones, 1987). Notwithstanding this sustained depoliticization, the period was nevertheless marked by numerous institutional reforms (see figure 1) which 
progressively redefined equipment as a public problem and the instruments established to deal with it.

\section{Figure 1 about here}

Indeed, Uttley distinguishes three periods in the history of British defence policy after 1945 (2001, p. 115-133). Between 1945 and 1960 the emphasis was on national selfsufficiency and a 'broad-front' approach. After the war, the United Kingdom possessed an across the board arms industry. The problem of government, and indeed most of the defence industry as a whole, was to maintain a diversity of companies for each type of equipment ('the multiplicity of companies' concept) and, in many cases, to support the development of two or three different manufacturers within each type of equipment.

By contrast, the 1960s and 1970s were marked by the building of large 'national champions' and the development of international partnerships in military equipment, in order to tackle a fragmentation of national producers now redefined as problematic. To achieve this goal, the governments of the day encouraged the mergers of manufacturers, sometimes through nationalizations. It was also at this time that the Ministry of Defence (MoD) became directly involved upstream in the design of equipment, which, moreover, became more costly and risky for each industrialist to develop independently. This also motivated the UK's initial international partnerships, particularly with France (Jaguar, Gazelle, Lynx, in 1965 and 1967).

Finally, the period between 1979 and 1998 became an era of 'competitive procurement policies' ostensibly designed to treat the following 'problem': rising equipment costs 
and ‘a funding gap' between defence resources and British military commitments. As Uttley notes, the Conservative government of these years:

'could have addressed the 'funding gap' by increasing the defence budget, reducing service personnel and salaries, or abandoning a major defence role. (...) Instead, the preferred solution was to bring procurement costs under stringent control' (2001, p. 121-122).

Indeed, as other authors have also stressed (Jones, 1987; Dorman, 2002; Erbel, 2017), as of 1979, and particularly in the 1990s, the 'defence consensus' was broken. Conservative governments of this period achieved this largely through the implementation of Compulsory Competitive Tendering in various areas of the public sector. In the case of defence, their roadmap was particularly clear. For example, Lord Levene, Chief of Defence Material from 1984 to 1990, recalls:

When I got the job, Margaret Thatcher said to me: 'Ok, this is your charter: your job is to buy the best possible equipment for the British armed forces, on the best possible terms. P.S.: your job is not to keep the British defence industry in a manner to which it has become accustomed.' And that was what I did for six years. (Interview, London, November 2017).

Indeed, in the 1980s and 1990s a clear polarization of the debate surrounding defence equipment and support emerged and took root in the UK. This diametrically opposed proponents of a defence-specific approach to industrial policy in the name of 'a defence industrial base' on the one hand, and neo-liberals armed with a generic approach to public procurement on the other. 
If the impact and transparency of that cleavage has been well documented, the period since the late 1990s has proved more difficult to label and unpack. The coming to power of New Labour in 1997 is generally presented as a continuation of Conservative policy. During a period of reformulation of the British army's objectives, increased engagement in international peacekeeping missions, and the subjection of military assets to foreign policy objectives (Forster, 2010, p. 153), Labour’s defence policy was seen by virtually all commentators as marked by the desire to import private sector management methods into resource management. In terms of equipment acquisition, this 'managerialism' translated into the slogan 'Smart Procurement'. Purchases were to be 'faster, cheaper, better’ (SDR, 1998). To this end, the MoD promoted public-private partnerships (PFIs), reorganized the Army, and extended defence marketization (Deakin, 2010, p. 140 sqq). Indeed, the Labour governments of 1997-2010 are most frequently presented in the existing literature as having deepened mechanisms to accompany the privatisation of the defence sector (Dorman, 2002). More generally, existing analysis of UK defence policy explicitly or implicitly concludes that a new consensus on how to manage the defence industry within a neoliberal frame was established and institutionalized in the 1990s. Privatisation, outsourcing and budget austerity are seen as its main elements (Hartley, 1991; Uttley, 2001).).

Notwithstanding this widespread agreement amongst specialist commentators, many also accept that the model which emerged in the 1990s generated a number of tensions, particularly between the values of the military and what Deakin calls 'the commercial ethos' (2010, p. 149-150). Indeed, the very place of equipment acquisition and support within defence policy remained a key issue throughout Labour's period in office. This became particularly clear in 2005-2007 during Paul Drayson's first term of office as 
Minister for Procurement and its culmination in 2007's White Paper on Defence Industrial Strategy, both of which was seen by many as supporting industrial policy favourable to 'national' firms such as British Aerospace or Babcock. In short, before 2010 the debate between neo-liberals and proponents of industrial policy had never been completely settled in terms of a stabilized problem definition and policy instruments. Nonetheless, at a time marked by intense engagement in Afghanistan and across the board 'austerity' cuts in government spending, Conservative politicians used the legitimacy of their electoral victory in May 2010 to explicitly seek rapid change in the governance of defence equipment. Indeed, their initial actions appeared to settle the frame of defence procurement once and for all by reiterating the need to push the ‘commercial approach' to its supposedly logical conclusion via the Defence Reform Act of 2013.

The empirical question we have therefore sought to answer is whether the arrival into office of the Conservative-Liberal coalition, then its Conservative successor, has caused deep, institutionalized change in problems, instruments and practices? Has it deepened the institutionalization of a 'neo-liberal' frame for defence procurement? Alternatively, has a new frame of procurement and support been created? If so, what does this new frame consist of? What are its properties and what does it mean in terms of governmental regulation of the British defence industry as a whole? Moreover, if deep change has indeed occurred, what political work brought it about?

\section{When 'Capability' Becomes the Problem}

A first means of answering the above question is to examine more closely how representatives of the two post-2010 governments have defined defence procurement and equipment support as a problem. Examined from this angle, our documentary, 
interview and content analysis all reveal that since 2010 the word 'capability' has become a central component of the lexicon of UK Secretaries of State for Defence and their Ministers for Defence Procurement. The importance of capability as a new political defence obligation is also reflected in normative incentives, calls to order, which are also found in various forms of public policy audit. Thus, in the report of the House of Commons Public Accounts Committee on the 'Management of the Typhoon Project', the MOD is blamed for failing to demonstrate the ability of the Typhoon to fill the 'capability gap' created by the concomitant scrapping of the Jaguar (specialized in ground attack) and Tornado F3 (specialized in air defence) aircraft (Public Accounts Committee, 2011).

Of course, the term itself is by no means a recent invention. Originating within engineering, the concept of capability first referred to the maximum point beyond which a structure can no longer support the function for which it was designed. When applied to military issues, the term capability has become increasingly used since the end of WWII and has gradually became a key concept in defence policy in many countries. After the end of the Cold War, a Capability-Based Approach has been widely recognized as one of the most legitimate ways to plan and measure military performance (NATO, 2003). In the UK, the concept of capability is part of a transformation of the product-service supply dynamics in the defence industry due to the imposition of through-life management (Miemczyk, Howard, Johnsen, 2014), which consists in particular of taking into account the cost of owning equipment which can account for up to $70 \%$ of budget for any item of defence equipment. At a more general level, the military capability of a state, defined as 'the effectiveness of their coercive arms', is described by the RAND Corporation as the 'ultimate yardstick of national 
power' (Tellis et al., 2000, p. 133). However, in examining the British case more closely, our archival analysis and elite interviews first revealed to us that the term capability has been defined and used quite differently by a range of actors, most notably between representatives of either Labour or the Coalition governments and their respective experts. In order to analyse this heterogeneity further, we subsequently decided to use computerized content analysis (see Box 1), to unpack usages of 'capability' within ministerial speeches in general, then to analyse them more deeply by delving into associations made between 'capability' and 'value for money.'

Box 1: Methodology of our Content Analysis.

Our dataset comprises 155 speeches made by seven British Secretaries of State for Defence (Reid, Browne, Hutton, Ainsworth, Fox, Hammond, and Fallon) and four Ministers for Defence Procurement (Drayson, Taylor, Luff, and Dunne) who held office between 2006 and 2016. Delivered in different places and contexts, they first illustrate the diversity of discursive activity of politicians. Nevertheless, statistically the challenges raised by this diversity can be partially reduced through embracing the sheer volume of text these speeches have produced. In terms of their content, these speeches were analysed using the Rtemis package of $\mathrm{R}$ and Iramuteq software through which the Reinert method is implemented. This method is designed to extract what Max Reinert, its creator, calls 'lexical worlds': 'the speaker, during their speech, invests in successive different worlds which, by imposing their respective properties, impose a specific vocabulary upon discourse. The statistical study of the distribution of this vocabulary aims at tracing these 'mental rooms' that the speaker has successively inhabited. Indeed, the traces left behind are perceptible in terms of 'lexical worlds'.' (Reinert, 1987). 
The 'presence rates' calculated below correspond to the number of occurrences of a word as regards the occurrences of all words in a given part of the corpus. For example, if the term 'capability' has a presence rate of $0.27 \%$ in 2006, this means that its 37 occurrences in the 2006 speeches represent $0.27 \%$ of the 13,764 occurrences present in the speeches given in 2006. This indicator avoids the bias that a simple consideration of the number of occurrences would lead to given the differences in numbers between the different modalities of the different variables (such as the fact that there are more Conservative speeches than Labour ones in the dataset).

\subsection{Varieties of 'capability'}

To begin with, we conducted some straightforward discourse analysis in order to reveal possible 'policy vocabulary breaks' within our overall database. Accordingly, Table 1 summarizes the ten most quantitatively important words in the speeches of the Secretaries of State for Defence. In turn, this provides an initial take on the differences in discursive structures used by Labour and Coalition speechmakers.

\section{Table 1 about here}

To delve more deeply into usages of the term 'capability', the structure of our Secretaries of State's database was then visualized on a factorial plane (figure 2). In the case at hand, this method enabled us to distinguish between two further sets of data. The first identifies the most distinctive themes of the speeches by Labour Secretaries of State. It shows that they focused above all on the international events of the period (2006-09), particularly British interventions in Iraq and Afghanistan. Conversely, the 
typical themes of speeches by Conservative Secretaries of State, with the exception of during the Libyan intervention, focused almost exclusively upon domestic policy issues: questions concerning Scotland and military reserves, but also and above all issues relating to the defence industry and the defence budget. At the heart of the latter dataset lies the word capability.

\section{Figure 2 about here}

The word capability was therefore present throughout the period studied but, under different governments, was not given the same centrality or meaning. This can, of course, partly be explained in terms of the varying degrees of British military action that occurred over the period. Nevertheless, this does not explain everything. Consequently, we then used a further sequence of content analysis to measure the rate of presence of 'capability' in a range of White Papers and defence reviews stretching back to the 1950s. Figure 3 charts this usage over time.

\section{Figure 3 about here}

This graph most obviously shows the progressive growth in usage of the term capability, but it also highlights a break in 2010. At this point, the presence rate of the term was multiplied by 2 , and this despite the fact that the review in question was signed off by Bob Ainsworth, a Labour Secretary of State for Defence. Revealingly, a similar break with past practice can be seen in the speeches given by the Secretaries of State for Defence and Ministers for Defence Procurement since 2006 (figure 4). 


\section{Figure 4 about here}

Generally speaking, the term capability has therefore been used much more by Conservative Secretaries of state and ministers (presence rate of $0.57 \%$ ) than by representatives of the Labour Party (0.30\%). Indeed, this effect is reinforced if only the speeches of the Secretaries of State for Defence are taken into account. The presence rate of the term 'capability' is three times higher for a Conservative Secretary of State as compared to a Labour one $(0.60 \%$ vs $0.24 \%)$ whereas it is more equally spread amongst Ministers for Defence Procurement's speeches $(0.46 \%$ for Labour against $0.51 \%$ for Conservatives).

More importantly, the use of the term capability varies considerably. In the Labour dataset, capability is almost always defined as an instrument of international diplomacy. Indeed, the word is the $7^{\text {th }}$ most important contribution to a lexical class where the most significant terms are 'NATO', 'Alliance', 'EU', 'Commitment', 'Need', 'Strategic', 'Member’, 'Nation', 'Challenge', 'Unite', 'Play’ or 'Partner'. Examples include the British contribution to NATO's 'capabilities', the 'capability' of allies to achieve their objectives, the 'need' to challenge the 'capability' of diplomatic 'partners'. For example:

We will need more effective international institutions. The UK will need to remain globally influential and engaged to shape those institutions and their actions. Our defence capability will need to reflect that global role. (Speech by Bob Ainsworth, Secretary of State for defence, to King's College, London, $15^{\text {th }}$ September, 2009).

Multinational operations can frustrate, we all know that, and there are areas in which some of our partners must improve usability and capability. (Speech by John Hutton, Secretary of State for defence, to International Institute of Strategic Studies, London, $11^{\text {th }}$ November, 2008). 
As a measure of military potential, the 'capability' of Labour's ministers was therefore mainly mobilised to make arguments relating to international power relations. For the Conservatives, however, this usage of the term disappeared. Here 'capability' no longer participates in the lexical class of diplomatic relations, but in two other lexical classes: the management of relations with industrial suppliers on the one hand, and the management of the national budget on the other.

From the first of these perspectives, the term capability is used alongside the forms 'Industry’, 'Export', 'Innovation', 'Supplier', ‘Technology’, 'Market', 'Contract', 'Business', 'Sector', 'Commercial', 'Customer' and seems to fall within the lexical field of defence economics. From the second, 'capability' is found alongside words such as 'Budget', 'Programme’, 'Defence’, 'Deficit', 'Spend', 'Review’, 'Decision’, 'SDSR', 'Sustainable' and is thus consistently linked to the management of public finances. The capability in question is therefore essentially that of the UK armed forces' equipment. This, is turn, is seen as a product of government working with its various industrial 'partners', i.e. companies and corporations:

We are moving towards a period of growth with greater opportunities for industry as we build the capabilities upon which our future force 2020 will rely. (Speech by Liam Fox, Secretary of State for defence, to The Defence and Security Equipment International, London, $13^{\text {th }}$ September, 2011).

We have protected our research and development budget and we are working with UK industry to set up a new defence solutions centre which will create the capability and the technology to respond to future international opportunities (Speech by Michael Fallon, Secretary of State for defence, to International Institute for Strategic Studies Shangri-La Dialogue, Singapore, 30 ${ }^{\text {th }}$ May, 2015). 
This shift from the lexicon of diplomatic relations to that of industrial performance constitutes an important break with the past. From the point of view of the Coalition then Conservative governments, the role of the MoD:

'is to ensure that we and our industry partners work effectively together to deliver the battle winning capabilities that our armed forces need at a cost that is value for money for the taxpayer' (Speech by Philip Hammond, Secretary of State for defence, to SSAFA's support of the armed services, London, $21^{\text {st }}$ October, 2013).

Procurement and equipment support policy is thus presented as 'a way of 'pumppriming' industry and directing investment to focus on the capability of the future' (Speech by Michael Fallon, Secretary of State for defence, to Defence Innovation Initiative, Spitalfields, $16^{\text {th }}$ September, 2016). The question to be addressed by all concerned thus became 'how we produce capability in an environment of constrained resources’ (Speech by Philip Hammond, Secretary of State for defence, to Royal United Services Institute: Land Warfare Conference 2012, Westminster, $7^{\text {th }}$ June, 2012). In summary, 'capability' is conceived of as a way of articulating the relations between the purchasing state -called upon to become an 'intelligent customer'- and the providers of defence goods and services. Within this frame, 'capability' thus refers to a particular form of organized social relations for regulating the defence industry, which are analysed further in sections 3 and 4 .

\subsection{How Capability can transform 'Value for Money' into 'Value Management'}

More fundamentally, this new way of posing the public problem of procurement renews a key theme in the making of British public policies since the late 1970s; the question of 
'value for money'. Of course, to some extent 'value for money for the taxpayer' has always been a requirement of those in charge of public spending (Wildavsky \& Caiden, 2004). Regardless of their raison d'être, public expenditures have been justified to the extent that they demonstrate a good 'quality/price' ratio. But this principle has a more specific history in the case of defence in the UK. According to Uttley, 'value for money' has been 'the guiding principle in the procurement process' of the MoD since the arrival of a Conservative government in 1979 (Uttley, 2001, p. 122; Bourn, 1994, p. 1). Indeed, this way of defining the problem for government around 'defence' as a public asset is emphsized by Hartley:

'In 1990-1991, Britain’s defence budget exceeded $£ 21$ billion. A budget of this size with its sacrifices of hospitals, schools and roads as well as of private sector goods and services (e.g. cars, videos, holidays) is obviously a source of public concern. Questions have to be asked about the 'appropriate' size of the defence budget. (...) Society is interested in the efficiency with which defence resources are used and whether it is possible for Parliament and the taxpayer to assess such efficiency.' (Hartley, 1991, p. 29).

Problematized in this way, military expenditure therefore 'had' to be costed and justified more clearly than any other public expenditure precisely because of what is depicted as its 'morally sensitive nature'. Moreover, usage of this expenditure 'had to become' particularly efficient. Nevertheless, in our dataset the expression 'value for money' per se is relatively rare: it appears 75 times in the database and its distribution is uneven: $87 \%$ of the occurrences stem from Conservatives locutors. Indeed, their usage rate is more than twice as high than it is for Labour politicians (figure 5).

\section{Figure 5 about here}


Of course, the speech acts of these Conservative politicians occurred in a historical context where, following the financial crisis of 2008, budgetary 'austerity' became an international norm (Blyth, 2013). Partly as a consequence, between 2009 and 2015 British military spending fell by $£ 8$ billion in real terms (Figure 6). The insistence on 'value for money' is thus part of a more generalized transformation of the narrative of managing limited budgetary resources 'better'. Indeed, within the database of Conservative speeches, occurrences of the term 'money' are a reminder of the MoD's 'moral duty' to manage public money and - for obvious reasons - a means of denouncing Labour's 'budgetary negligence' over the preceding period. This was particularly so in the speeches made by Liam Fox when Secretary of State for defence.

\section{Figure 6 about here}

But the construction of the procurement problem using the term 'capability' also made it possible to balance budgetary efforts with military imperatives. This viewpoint is synthesized by words attributed to Lord Drayson, former Ministry for defence procurement, by one of our interviewees: defence actors ‘don’t want to kill themselves just to show they are competing' (Interview with senior DE \& S official, Bristol, February 2018). From a managerial perspective, 'capability' thus becomes the numerator of a fraction within which 'defence expenditure' is the denominator - the formula at the heart of what many MoD civil servants call 'value for money'. Under certain accounting conditions, notably the inclusion of ownership costs, these actors assume that this formula will also enhance the sustainability of military investments. Another DE \& S official also spoke on interview of how interpretations of the value for money imperative have recently been renewed: 'To what extent do we pursue absolute 
value for money? The MOD’s chief economist still thinks we don't do this enough. We drive those economists mad! Because in fact, I am allowed to interpret value for money more broadly than in the past' (Interview with DE \& S official, Bristol, February 2018).

How has this challenging of the mantra of value for money become possible? What change in the dispositions and social positions of certain actors has brought this about? To begin to answer these questions, it is now important to revisit how the instruments of managing and running British procurement have been revamped over the past ten to fifteen years.

\section{Instrumentation: Organizational and Implementation Change}

Indeed, what have British governments actually done on the basis of the reformulation of the public problem of procurement and defence support in the name of 'capability' presented above? By examining changes in governmental organization and the policy instruments used to regulate the defence industry, we show below that in the UK redefining Defence's problem in terms of capability has occurred alongside the agencification of the MOD and, secondly, through an overhaul of the very contracting processes which equipment acquisition and support entails.

\subsection{The 'agencification' of acquisition and support activity}

The British MOD did not wait for the coalition government to re-organize procurement. As early as 1971, a department named the Procurement Executive (PE) was created within the MOD and headed by a Chief of Defence Material. In 1999, the PE was

replaced by the Defence Procurement Agency (DPA) as part of a general process of agency creation during the 1990s (Pollitt et al., 2005, p. 105). Subsequently, in 2006 the 
Defence Equipment and Support agency (DE\&S) was created by merging the DPA and a logistics agency established in 2000 (the Defence Logistics Organisation or 'DLO'), then moving staff out of London to an agency based on a new site in Bristol. The DE \& $\mathrm{S}$ was thus in place when the coalition government took office. However, this agency then became the subject of a series of attempts to render it more like a private corporation.

Firstly, since January 2011's replacement of General Kevin O’Donoghue as Chief of Defence Material, the DE\&S has been headed by civilians (Bernard Gray from 2011-15, then Tony Douglas for the period 2015-2017). Secondly, and more deeply still, following a controversial period of experimentation in 2012-13 which ultimately abandoned the actual privatization of the DE\&S, in 2014 this agency became 'a bespoke trading entity' which, although remaining in the public sector, has been given 'freedoms' and 'flexibilities', such as no longer having to apply civil service pay rules (National Audit Office, 2015, p. 8).

Overall, the coalition government of 2010-15 rapidly equipped itself with expertise and legislation-based legitimacy for changing the roles and procedures of government, the civil service and the armed forces within defence equipment and support procurement. On this basis, it also deepened two organisational transformations regarding procurement implementation: an agencification of a significant part of the MoD and privatization of much of the state's capacity to maintain its own military equipment via externalization of this task to private companies. In short, the recent history of procurement in the UK can be seen as one of the institutionalization of the DE \& S's organizational autonomy. 
Nevertheless, this autonomy has also been challenged by how central government itself has reorganized itself in order to orientate the procurement processes run by DE\&S. Since 2010, the work of DE\&S managers has been described by themselves as highly scrutinized within that organization itself. As one of our interviewees from the DE\&S, repeatedly underlined, their daily work now involves the production of large quantities of data to feed monthly 'dashboards'. Moreover, according to him, this 'professionalization' of procurement has had numerous advantages. For example, it generates an argumentative basis for expressing points of view within the DE \& S: 'you have to know your numbers, it's all about the data, the evidence. You can't argue with the numbers [...] I think it's positive'. (Interview with senior DE \& S official, Bristol, February 2018).

We claim this is precisely why from 2010 onwards, the objectives of DE\&S have been reformulated in terms of 'capability'. For example, in 2013, General Sir Nick Houghton, then Chief of Defence Staff of the British Army, publicly stated that the purpose of defence spending was to 'maximize military capability' (Guardian, 2013), a mission devolved - among other things - to Capability Directorates within each of the armed forces headed by a highly senior officer.

Indeed, since 2010, and because of the change in problem definition presented in the previous section, the terms of debate regarding the best instruments for procuring and supporting defence equipment have shifted away from simply choosing what equipment to buy, towards criteria used to evaluate performance throughout the life cycle of the product in question. This thereby takes into account the cost of equipment support, 
together with the contractual arrangements this necessitates. Indeed, the actors at the centre of this process all hope that 'maximizing capability' will provide a general organizing principle for overcoming the dichotomy between procurement and support. However, this displacement of the locus of political work from defining the objectives of defence policy towards its supposedly more straightforward 'management', has nevertheless generated other uncertainties regarding the best instruments and indicators with which to define the operational goals and tasks of policy implementers, and those in the DE\&S in particular.

\subsection{Contracting for Capability: Bridging the Gulf between Procurement and} Support

According to Bourn (1994: 17) bridging the gap between procurement and support began in the 1980s. A few years later, this effort was translated into specific accounting practices, such as the emphasis on ownership costs in acquisition processes. The idea was to take into account not only acquisition costs but also support costs throughout the life of the equipment. However, such a reform has not proved easy to adopt and implement. As indicated in the Strategic Defence Review of 1998: 'Historically, the functions of requirement definition, procurement management and through-life support have been organisationally separated' (SDR, 1998). As a result, it has consistently proved difficult to gather the information necessary for full cost calculations. As Bourn notes:

The most significant obstacle to effective life cycle costing is the collection of equipment based data. The Ministry of Defence has developed an information technology framework, within which individual Services have incorporated the information needs of life cycle costing into their individual logistics information strategies. These strategies can, however, take up to to (sic) ten years to develop fully (Bourn, 1994, p. 31). 
By 1994, the establishment of life-cycle costing models for on-board equipment and armaments for sea systems in the Ministry of Defence had already cost $£ 9.5$ million and a further £0.7 million were planned (Bourn, 1994, p. 30). Overcoming the dichotomy between acquisition and support was proving to be a costly reform. It involved a rethinking of practices, a renewal of personnel but also of the organization itself hitherto divided between the acquisition and support functions but also structured by an overarching division between the three armed forces (air, land, sea).

This initiative had many consequences. In 1998, the SDR again recommended the use of a 'through-life concept', which render possible decision-making on the basis of a 'broader view of the equipment's life cycle' (MOD, 1998). Moreover, on many occasions during the 2000s, reform entrepreneurs, such as Bill Kincaid, underlined in public -and taught in defence colleges - the need for a 'through life' approach (Kincaid, 1997, 2001, 2008). In terms of governmental initiatives, this all resulted in a general reform of procurement practices named the 'Smart Procurement Initiative’ in 1997, later renamed 'Smart Acquisition' in 2002. As a House of Commons research paper notes, the reform established a 'through-life systems approach' covering both initial acquisition and in-service management of equipment as a priority (Taylor, 2003).

Under the Coalition, then the current Conservative governments, there has been an even more concerted attempt to go beyond the dichotomy between procurement and equipment support. This has taken the form of the attempt to contract between the DE\&S and manufacturers in ways that fit not only with the ideal of pure free markets, 
but with the current condition of markets, together with the resources and practices of the companies that compete within them.

Indeed, our empirical research in late 2017 and early 2018 reveals that today the DE\&S implements an overall approach to procurement which actually features a surprisingly wide range of procurement and support 'routes to market' and contracting methods. Consequently, if certain equipment has been purchased off-the-shelf on the basis of relatively simplistic value for money reasoning (e.g. the decision in 2015 to upgrade the US-produced Reaper drone), other decisions have entailed more complex analysis of capability (notably the decision in 2017 to externalize support for the A400M airlifter to Airbus: Giry \& Smith, 2019; and, by contrast, the development in 2015 of a long-term 'Submarine Support Partnership Arrangement’: Louth \& Taylor, 2015: 3). Although further research is needed on other arms programmes in order to verify and reinforce this claim, our study strongly suggests firstly that a variety of 'routes to market' is now institutionally embraced and, secondly, that the current British approach to procurement is now far from being dogmatically open-market centred (as too many outside observers rush to conclude). Indeed, the legitimizing discourse we often heard on interview of 'no one size fits all', has actually been translated into administrative practice in the form of specific policy instruments.

Moreover, all the 'routes to market' currently at DE\&S's disposal are now driven by an approach to military capability which refuses to separate out equipment procurement from that of its support during its operational 'life' in the armed services. In particular, 
this shift in approach is reflected in DE\&S’s ‘Improving Support Initiative’ (and, more generally, in its initiatives 'putting the S [for support] back into DE\&S'33).

Finally, legitimized more generally in the name of the public interest, the policy instruments adopted by DE\&S claim to both attract industry and ensure capability with minimal industrially imposed constraints ${ }^{4}$. In so doing, the organization claims to want to challenge pre-conceived ideas, orthodoxies and ingrained practices throughout the industry. In short, the instrumentation that has been produced since 2010 is a hybrid we label 'value management'. Located between the liberalization of markets and industrial policy, it is structured by the way equipment support tasks are put on the market.

In summary, looking back at the post 2000 period the emergence of two key conditions rendered possible the emergence of 'value management' as a meaningful and powerful policy frame. Firstly, agencification helped increase the relative autonomy of the procurement function from political and military actors. Specifically, by specializing and professionalizing this activity, the DE\&S as an agency has enabled contractualization to be based much more upon data which, rightly or wrongly, is seen by the protagonists themselves as technically superior and politically neutral. Secondly, DE\&S agents have subsequently had the freedom to develop a procurement concept that

\footnotetext{
${ }^{3}$ This expression has been used repeatedly by this organization’s CEO from 2015 to December 2018, Tony Douglas, as well as by many other senior management officials, notably in DE \& S's own internal journal (see, for example: Desider. The Magazine for Defence Equipment and Support, December 2015 - Issue 90: 9; march 2017 - Issue 105 : 11. For content analysis of this magazine see Author, forthcoming).

${ }^{4}$ For examples of this discourse, see the MOD’s 2017 White Paper, 'Industry for Defence and a Prosperous Britain: Refreshing Defence Industrial Policy’.
} 
is less dependent upon, and relatively insensitive to, changes in government and thus over-arching ideologies.

\section{Discussion: from a Polarized Cleavage to 'Value Management'?}

Indeed, this relative autonomy has contributed to the development of a new ethos that our research strongly suggests is currently in the process of taking root within the world of British procurement and equipment support. By rejecting the alternatives promoted by neoliberal 'headbangers' or 'defenders of the national industrial base', many British actors at the centre of acquisition and support have instead promoted an ethos of 'value management' which, through combining elements from each of the pre-existing and firmly opposed alternatives, has nevertheless generated a new policy frame.

\section{1. 'Headbangers' vs. 'Industrial Base Defenders'}

Throughout the history of procurement and equipment support described earlier in this paper, we have been struck by the gulf that has separated two framings of this issue, but also by political work done to discover a means of navigating between them. On the one hand, since the 1980s the argument that the defence industry should be treated just like any other through applying so-called 'free market' principles, has clearly gained ascendency. From this point of view, having consulted the military about its needs, the government should simply publish a call for tender and then buy equipment or support from the supplier who would provide it satisfactorily at the lowest cost. Where possible, this should be brought 'off the shelf' and indifferently from national or foreign manufacturers and support entities.

Moreover, the holders of this belief and value system also consider that public 
companies are always less efficient than private ones. Consequently, they have led the way in calling for the privatisation of such bodies, together with the externalisation to private contractors of the services they previously provided to the equipment when in use by the armed services. In this way, it is argued, both the military and government can also become 'leaner', more efficient, and thus better 'customers' for the private builders of defence equipment and its support. Indeed, for them an indicator of being a good customer is the ability to drive down prices during the selection of contractors and the negotiation of their respective contracts. This in turn entails bringing in personnel from other industries into the DE\&S in order to import and spread the cost-cutting and negotiating skills they are reputed to have developed in other commercial environments. In short, this first approach to defence procurement and support can be labelled 'neoliberal' because the value hierarchy at its heart not only prioritises the liberty of private enterprise, but also the state's obligation to structure markets in a way that enhances both this freedom and the alignment of governmental logics and practices to engender it, as a self-reinforcing whole. If Conservative politicians and their declared followers have clearly been in the vanguard of institutionalizing the neo-liberal model, its building, up-dating and maintenance has also been carried out by a much wider set of politicians, civil servants, military officers, experts and representatives of private companies, many of whom would not necessarily self-declare as neo-liberal, or even being on the right of the political spectrum (most obviously many actors involved in the Labour administrations of 1997-2010).

Notwithstanding the currently dominant position of this neo-liberal approach, an alternative nevertheless continues to exist and be used to critique and amend it. The cornerstone of this second approach is that the defence industry is singular and should 
be regulated, and indeed embraced, accordingly. The first justification for this industry being seen as different is simply that the quality of the equipment produced and serviced for the military must be sufficiently high so that the objectives of the UK's armed services can actually be achieved, and this with the least possible loss of life or injury to its own personnel. This military justification dovetails with one that is used in industrial policy - because most defence equipment must last and retain high performance levels for such long periods, durable relationships between government and suppliers must be cultivated and encouraged. Although supporters of what we call this 'durable security' approach to defence procurement and support today rarely think that suppliers should be renationalized, they all believe strongly in the notion of a 'defence industrial base' which is anchored in Britain itself. Consequently, they favour calls for tender and contracting policy instruments which focus on the provision of quality equipment and services over time and, where possible, by suppliers who produce at least part of their goods and services in Britain, thereby contributing to the retention and development of technology, skills and R \& D capacity (see for example Louth \& Taylor, 2015). Indeed, on interview they frequently stigmatize their neo-liberal adversaries as cost-cutting 'headbangers' whose only concern is the short-term and 'price, price, price' (Interview, senior DE\&S official, November 2017). In short, according to proponents of durable security, the neo-liberals' insistence on the cost of defence policies, together with the short timeframe they use for making procurement decisions, actually prevents the generation of innovations that would make a difference on the battlefield, while developing British industry as a whole.

Not surprisingly, the neo-liberals themselves also denigrate proponents of 'durable security', most often as delusional utopians. For example, in Bernard Gray’s 2009 
report, be they politicians, military, civil servants or industrialists, the defenders of a national industrial base are victims of what the Gray report calls 'the conspiracy of optimism' who end up perverting the objectives of the acquisition function. By launching unrealistic, inadequate, expensive and sometimes unfunded armaments programmes - due to their 'aspiration for perfection' - they in fact only serve the interests of national defence companies rather than those of the country and its army. Indeed, on interview Lord Levene, who describes himself as 'clearly very unpopular with the defence industry', interpreted his unpopularity as a sign that he had done his job well by sticking to his definition of the problem and his ethos of 'business-like public service’ (Interview, November 2017).

\subsection{The Emergence of a New Ethos}

Given the prevalence over the last four decades of neo-liberal problem definitions, instruments and legitimation within British government in general and UK society more broadly (Farrall \& Hay, 2014), it comes as no surprise that the discourse surrounding defence procurement and support in this country has become dominated by this approach. Nevertheless, when one analyses in full the actual content of the practices of procurement and support in the UK, one also discovers that the neo-liberal approach is by no means hegemonic. We claim that this is because throughout this period other, usually less visible, actors have conducted political work to forge a middle way that combines elements from both the polarized approaches set out above.

Part of this political work has consisted in involving politicians in procurement and support issues. Once again, certain words played a key role here. For example, on interview an assistant to the House of Commons' Defence Committee described 'capability' to us as one of the 'buzzwords' of contemporary defence policy: 
'Unfortunately, procurement is sometimes quite technical and dry [...] It's not very sexy. It's not about going to exotic locations. It's about stuff [...]. So part of my challenge is to make it clear to members [of the Defence Committee] why this is important.' In other words, his work has involved making sure:

'that everyone is very aware, particularly in a moment where several (arms) platforms are potentially at risk from the capabilities degrowth we're talking about, why this is important, why it's important to emphasize that' (Interview, London, November 2017).

From the point of view of such actors, both the price-cutting 'headbangers' and the 'conspirators of optimism' share dated views on government-industry relations which do not sufficiently take into account the complexity of military, industrial and policy issues. Taking advantage of the space opened up by agencification, and by positioning themselves between the different influences exerted by more vociferous actors, these self-professed 'pragmatists' have developed a synthesis of neo-liberal and durable security problem framings and policy instruments. This position goes hand in hand with what is presented as the 'professionalization' of acquisition practices ‘to make MOD an intelligent customer' (Moore, 2016). Indeed, the most obvious manifestation of this approach is the multiple 'routes to market' scenario established by the DE\&S we set out in the previous sub-section. Revealingly, the first Minister for defence procurement of the coalition government, Sir Peter Luff, positioned himself as a spokesman for the 'value management' frame. On the one hand, Luff repeatedly stressed the advantages of a 'tough love approach' to private companies by the MOD:

I have a problem with the very idea that we have, or should have, 'a defence industrial base' (...) The old phrase 'sovereign capability' trips easily off the tongue. But it can lead to some pretty woolly thinking. The Defence Industrial 
Strategy of 2005 listed the capabilities industry had. And then said what government would do to protect them. This allowed everybody and anybody to claim that their capability was essential and that, implicitly, the MOD would have to fund it. An approach that proved unaffordable, and downright illogical in an age of rapid change (...). We're not going back to producing a long list of specific sovereign capabilities, effectively owned by specific companies, that we will protect. (...) The future lies in open systems. (...) Defence is a national business, but it is not an industry of the state. (Speech by Peter Luff, Minister for procurement, to Royal United Services Institute, London, $28^{\text {th }}$ June, 2012).

On the other hand, however, and crucially, Luff did not simply defend instead a 'buying off the shelf' strategy. Instead, he stressed the need to study 'the appropriateness' of any purchasing by the state:

This means buying off the shelf whenever possible and when appropriate. Where we need technological advantage for security we will maintain it (...). Another 'process' we can pursue is to build-in upgradability and/or spare capacity within the design from the outset, recognizing that such an approach will offer better value for money in the medium term. And we must be disciplined not to erode it as and when we inevitably look for short-term savings. (...) Having created the upgrade capacity, we need to find a smart way of exploiting it. (Speech by Peter Luff, Minister for procurement, to Helicopter capability briefing day, Yeovilton, $1^{\text {st }}$ May, 2012).

Anxious to defend this approach in more concrete terms by institutionalizing it, throughout his term of office Luff pushed his civil servants to produce a policy document, which eventually in 2012 became the White Paper on National Security Through Technology. Revealingly, this initiative drew the ire of neo-liberals and, in order to actually reach Parliament, was eventually watered down through the removal of its sector by sector annexes. Nevertheless, ever since, this White Paper has provided a source of support for both the proponents of 'durable security' and a range of more agnostic actors working on defence procurement and support itself, notably within the DE \& S. Indeed, the 'routes to market' roadmap and contracting instruments described 
in the previous section are the most obvious manifestations of what appears to be a new institutional order in the making for British defence procurement and equipment support.

\section{Conclusion}

It is too early to say whether the institutionalization of a new approach to procuring defence equipment and support has completely taken place in the UK. Nevertheless, by focusing upon the creation over the last decade of a new policy frame within which 'capability' is supposed to provide a principle for organising the social relations that regulate the defence industry, this article has opened up a new line of enquiry concerning what currently shapes the contemporary model of British procurement and equipment support. Moreover, we have begun to answer the question of why this governmental practice has recently changed. We claim firstly that 'capability' has gradually become a general objective of procurement policy to which all the stakeholders -politicians, military and industrialists- are now obliged to refer. Secondly, during its deployment within the DE \& S, this new frame has prompted a reinterpretation of the valuation criteria previously in force, such as the imperative of 'value for money'. Today these criteria are now based on forms of policy instrumentation which themselves reflect a reorganization of the procurement function and the development of ad hoc management tools. Moreover, this frame has been developed alongside the emergence of a specific ethos, proposing habits and rules for procurement which seek to go beyond the longstanding binary opposition between 'national industrial base defenders' and 'neoliberal headbangers'.

In general terms, our analysis shows that, at least to date, no renewed political consensus over defence procurement and equipment support has developed. Instead, our 
data reveals that not two, but three approaches to this issue -neo-liberal, durable security and value management- are now competing with each other in order to frame it as a public problem and generate policy instruments as well as legitimizing both within the defence industry and to a wider public. Consequently, the governing of British defence is structured by multiple tensions, which regularly come to the surface and this as much around specific instances of procurement as during publicized, set-piece debates over defence or industrial policy. Tracking 'capability', its meaning and its usages within organizations and inter-organizational relationships, provides a way into analysing this cleavage because, as our documentary, interview and content analysis underlines, it has become a key term borrowed by proponents of each approach in order to problematize, instrument and legitimate their respective arguments, practices and alliances.

Indeed, ultimately perhaps the most significant trace left by the concept of capability upon British defence policy is how Lord Levene, once depicted as the archetypal neoliberal cost-cutting headbanger, today conceives of effective, modern procurement practice:

What we need to do is to buy, say 350 torpedoes from a manufacturer who guaranties that we'll have 350 torpedoes available 365 days a year. Now, how many Torpedoes have to be produced? What spare parts need producing? Where does one keep them? How much does it cost to repair them? I don't wanna know. I want to buy capability. (Interview, London, November 2017).

\section{References}

Baylis J. (1989) British Defence Policy: Striking the Right Balance. New York: Palgrave MacMillan. 
Blyth M. (2013) Austerity: The History of a Dangerous Idea. Oxford: Oxford University Press.

Bourdieu P. (2000) Pascalian Meditations. Stanford: Stanford University Press.

Bourn J. (1994) Securing Value for Money in Defence Procurement. London: RUSI Whitehall Paper.

Deakin S. (2010) 'MOD PLC: New Labour, Managerialism, Marketisation and the Privatisation of British Defence Policy'. In: D. Brown, ed. The Development of British Defence Policy: Blair, Brown, and Beyond. London: Routledge, 139-152.

Dorman A. M. (2002) Defence Under Thatcher. London: Palgrave MacMillan.

Dorman A. M., Uttley, M. R. H., Wilkinson, B. (2016) 'The Curious Incident of Mr Cameron and the United Kingdom Defence Budget: A New Legacy?' The Political Quarterly 87 (1), 46-53.

Emmerich N. (2016) 'Ethos, Eidos, Habitus A Social Theoretical Contribution to Morality and Ethics’. In: C. Brand, ed. Dual-Process Theories in Moral Psychology. Wiesbaden: Springer, 271-295.

Erbel, M. (2017) 'The Underlying Causes of Military Outsourcing in the USA and the UK: bridging the persistent gap between ends, ways and means since the beginning of the cold war’. Defence Studies, 17 (2): 135-155.

Farrall S., Hay, C., ed. (2014) The Legacy of Thatcherism. Assessing and Exploring Thatcherite Social and Economic Policies. Oxford: Oxford University Press.

Forster A. (2010) 'New Labour’s Governance of the British Army’. In: D. Brown, ed. The Development of British Defence Policy: Blair, Brown, and Beyond. London: Routledge, 153-159.

Giry B., Smith A. (2019) 'Supporting Atlas: Franco-British Co-operation to Service Europe’s Military Airlifter', European Review of International Studies, forthcoming. 
Goffman E. (1974) Frame Analysis. An Essay on the Organization of Experience. Cambridge: Havard University Press.

Guardian (The) (2013) 'Defence chief: UK armed forces have good equipment but not enough people'. The Guardian, 18 ${ }^{\text {th }}$ December, 2013.

Gusfield J. (1981) The Culture of Public Problems. Drinking-Driving and the Symbolic Order. Chicago: University of Chicago Press

Hartley K. (1991) The Economics of Defence Policy. London: Brassey’s.

Jones P. M. (1987) 'British Defence Policy: the Breakdown of Inter-Party Consensus'. Review of International Studies 13 (2), 111-131.

Kincaid, B. (1997) A Dinosaur in Whitehall: The True Cost of Defence Procurement Bureaucracy. London: Brassey’s.

Kincaid B. (2001) 'Smart Procurement: Revolution or Regression?' In: R. Matthews, J. Treddenick, ed. Managing the Revolution in Military Affairs. London: Palgrave Macmillan, 175-190.

Kincaid B. (2008) Changing the Dinosaur's Spots: The Battle to Reform UK Defence Acquisition. London: Royal United Services Institute.

Lascoumes, P., Le Galès, P. (2007) ‘Introduction: Understanding Public Policy Through its Instruments’. Governance, 20(1): 1-21.

Louth, J., Taylor, T. (2015) 'Beyond the whole force. The concept of the defence extended enterprise and its implications for the Ministry of Defence'. RUSI Occasional Paper.

Miemczyk J., Howard M., Johnsen T. (2014) 'Exploring Product-Service Supply Dynamics in the Defence Industry’. In: Eßig M., Glas A., ed. Performance Based Logistics. Wiesbaden: Springer Gabler, 185-215.

MOD (1998) Strategic Defence Review Report. Supporting Essay Ten, July 1998. 
Moore D. M. (2016) 'Professionalism in Defence Acquisition: The Importance of Knowledge and the Concept of the Intelligent Customer’. In: K. Burgess, Antill, P. D., ed. Emerging Strategies in Defense Acquisitions and Military Procurement. Hershey: IGI Global, 242-262.

National Audit Office (2015) Reforming Defence Acquisition. Report by the Comptroller and Auditor General, HC 946.

NATO (2003) Handbook on Long Term Defence Planning. Research and Technology Organisation, RTO-TR-069.

Pollitt C., Talbot C., Caulfield J., Smullen A. (2005) Agencies. How Governments do Things Through Semi-Autonomous Organizations. New-York: Palgrave MacMillan. Public Accounts Committee (2011). Management of the Typhoon Project. Thirtieth Report, House of Commons.

Rochefort D., Cobb R. (1994) The Politics of Problem Definition. Lawrence: University Press of Kansas.

Smith A. (2016) The Politics of Economic Activity, Oxford: Oxford University Press.

Smith A. (2019) 'Travail politique et changement institutionnel : une grille d'analyse', Sociologie du Travail, 2019, 61(1).

Taylor C. (2003) 'UK Defence Procurement Policy’. Research Paper 03/78. International Affairs and Defence Section, House of Commons Library.

Uttley M. (2001) 'Defence Procurement and Industrial Policies'. In: S. Croft, A. Dorman, W. Rees, M. Uttley, ed. Britain and Defence 1945-2000. A Policy Reevaluation. London: Routledge, 115-133.

Wildavsky A., Caiden N. (2004) The New Politics of the Budgetary Process, London: Longman Classics (5 $5^{\text {th }}$ edition).

Worcester R. (1966) Roots of British Air Policy. London: Hodder \& Stoughton. 


\section{Figures}

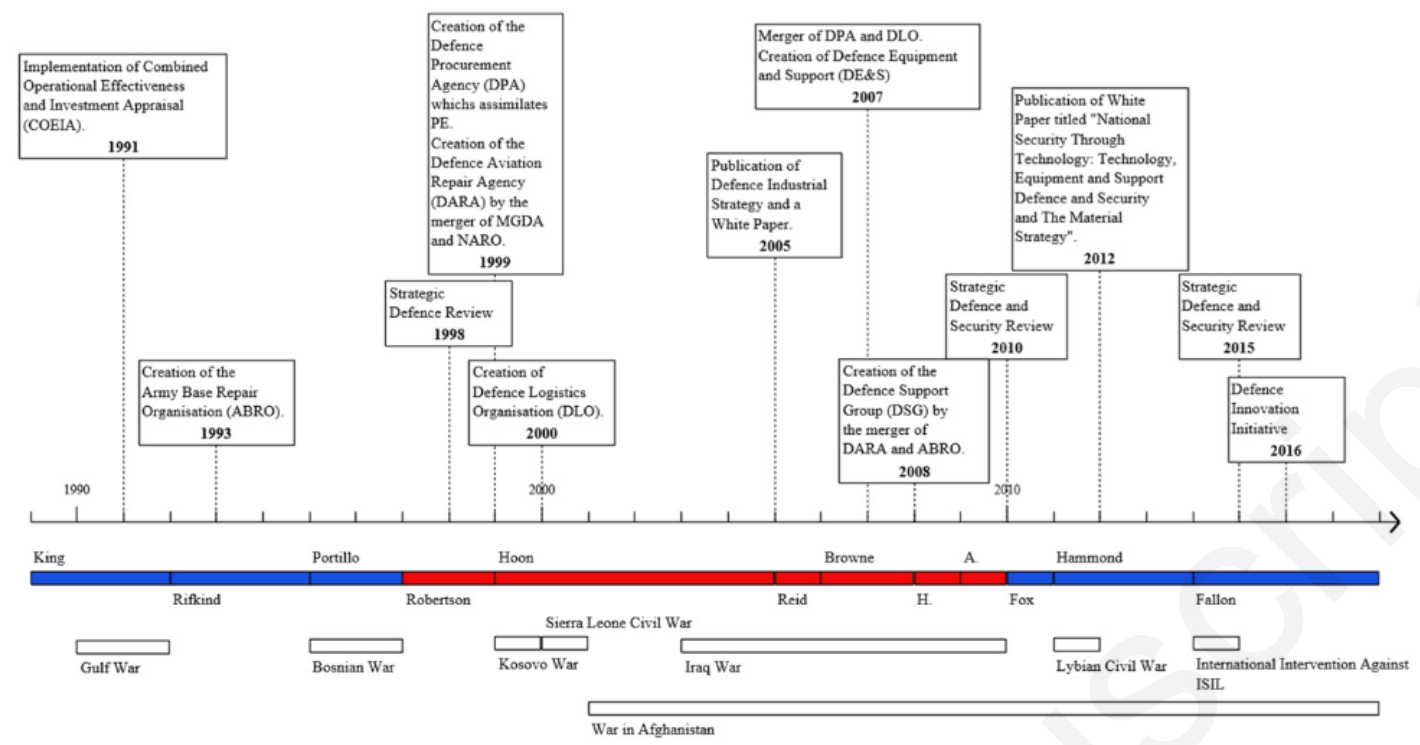

Fig. 1 A timeline of reforms affecting defence equipment (1990-2017) with names of Secretaries of State for Defence (Conservatives in blue; Labours in red) and major conflicts 


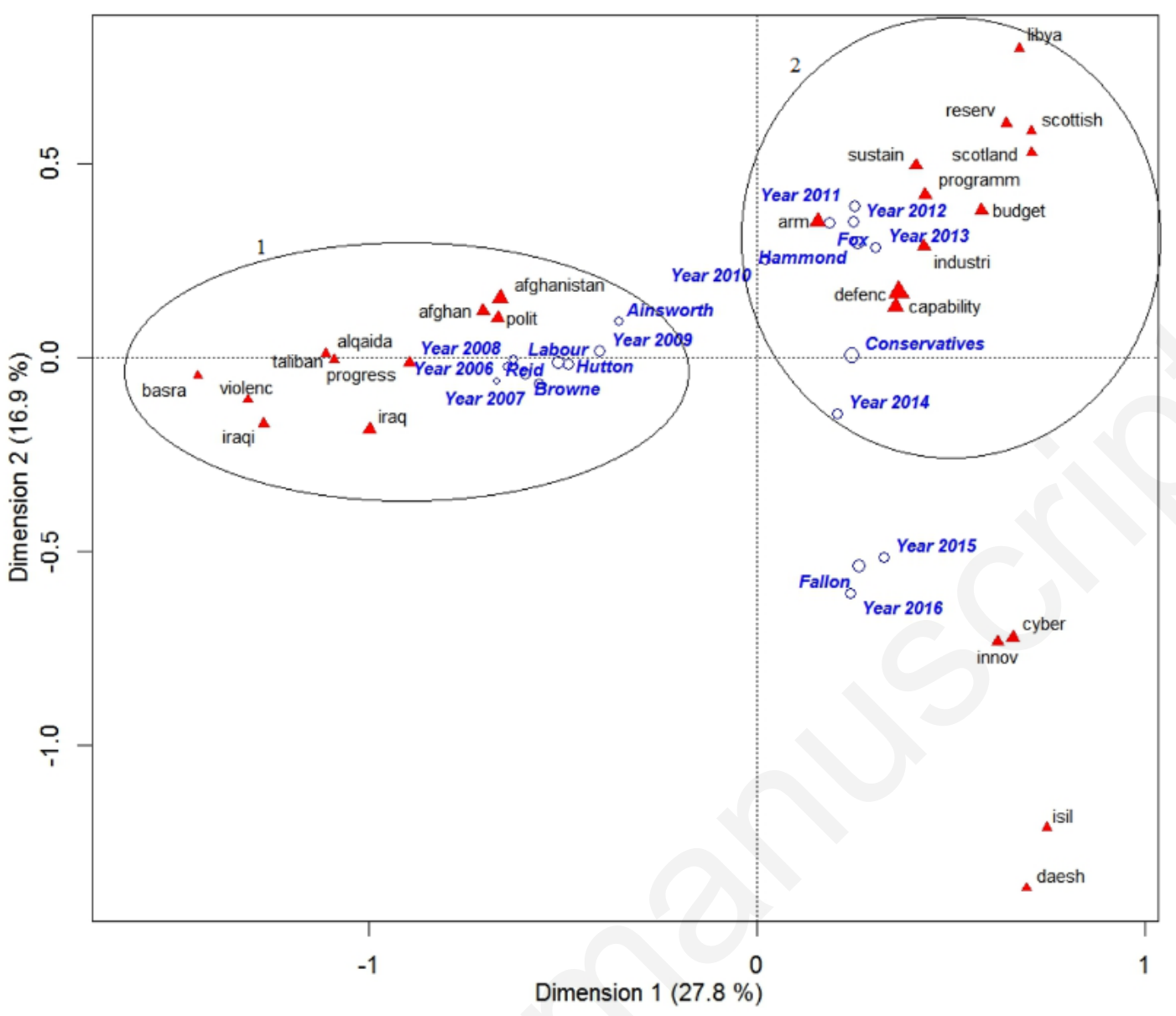

Fig. 2 A factorial analysis of defence Ministers' Speeches from 2006 until 2016

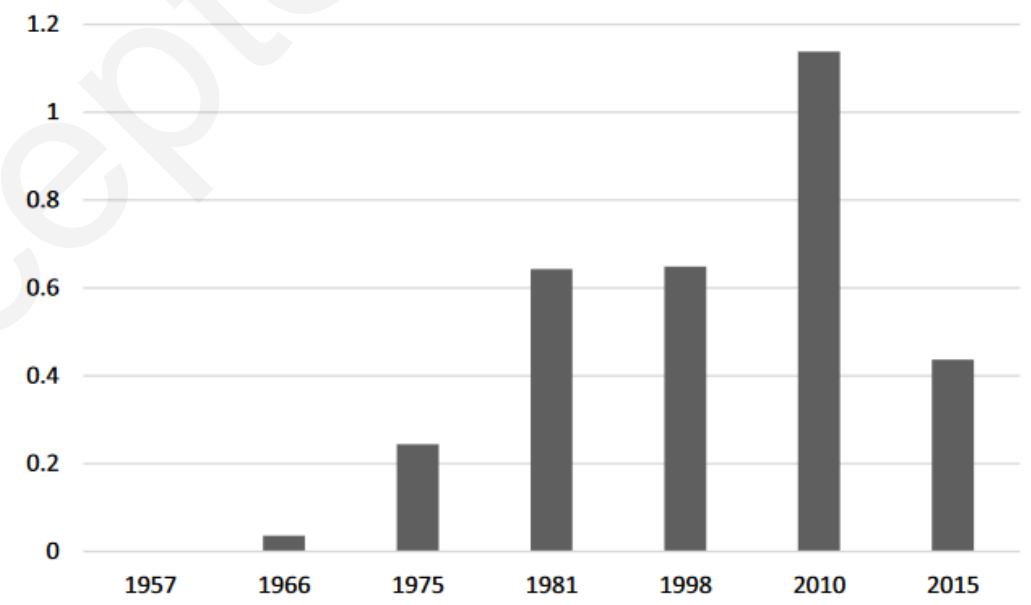

Fig. 3 Presence rate of the word 'capability' in British defence White Papers and reviews between 1957 and 2015 


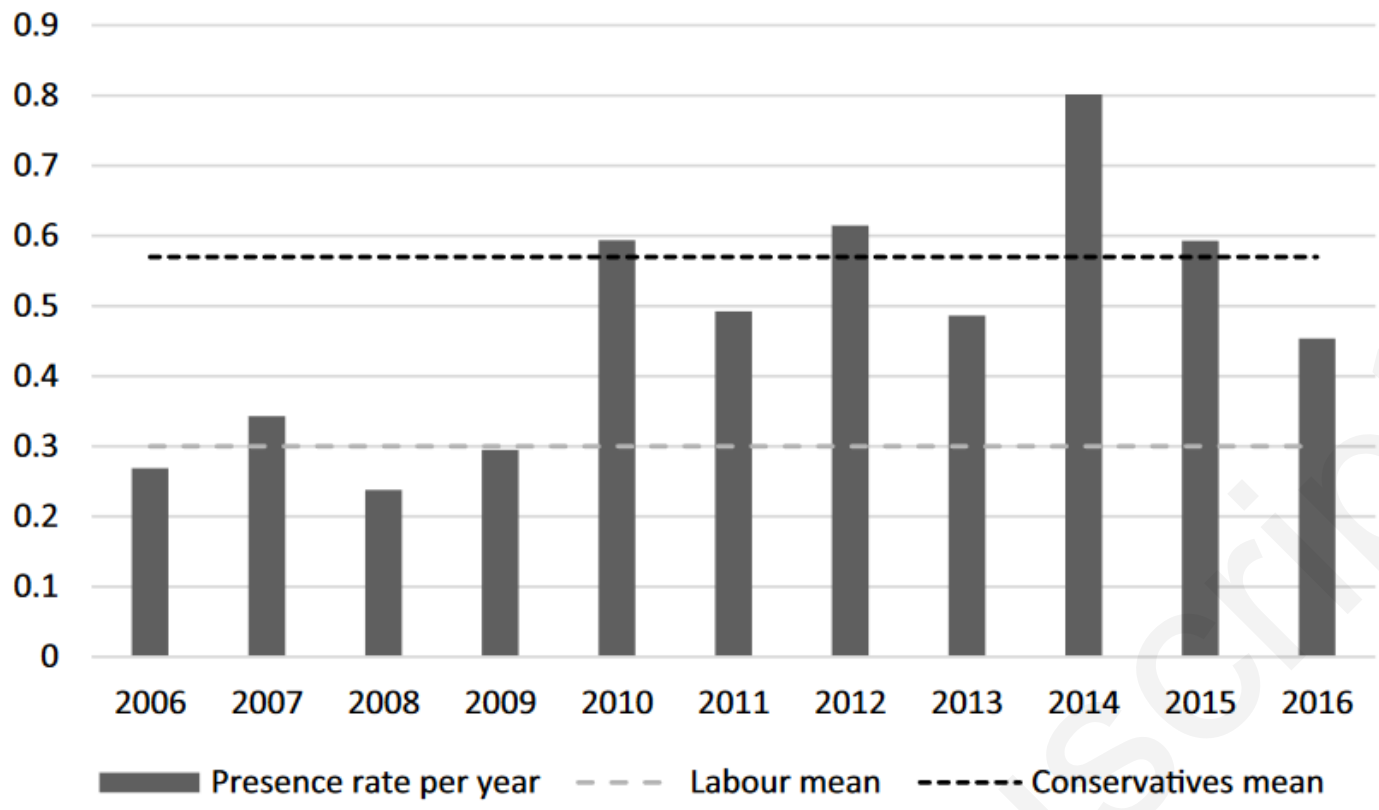

Fig. 4 Presence rate of the word 'capability' in speeches by the Secretary of State for Defence and Minister for Defence Procurement per year

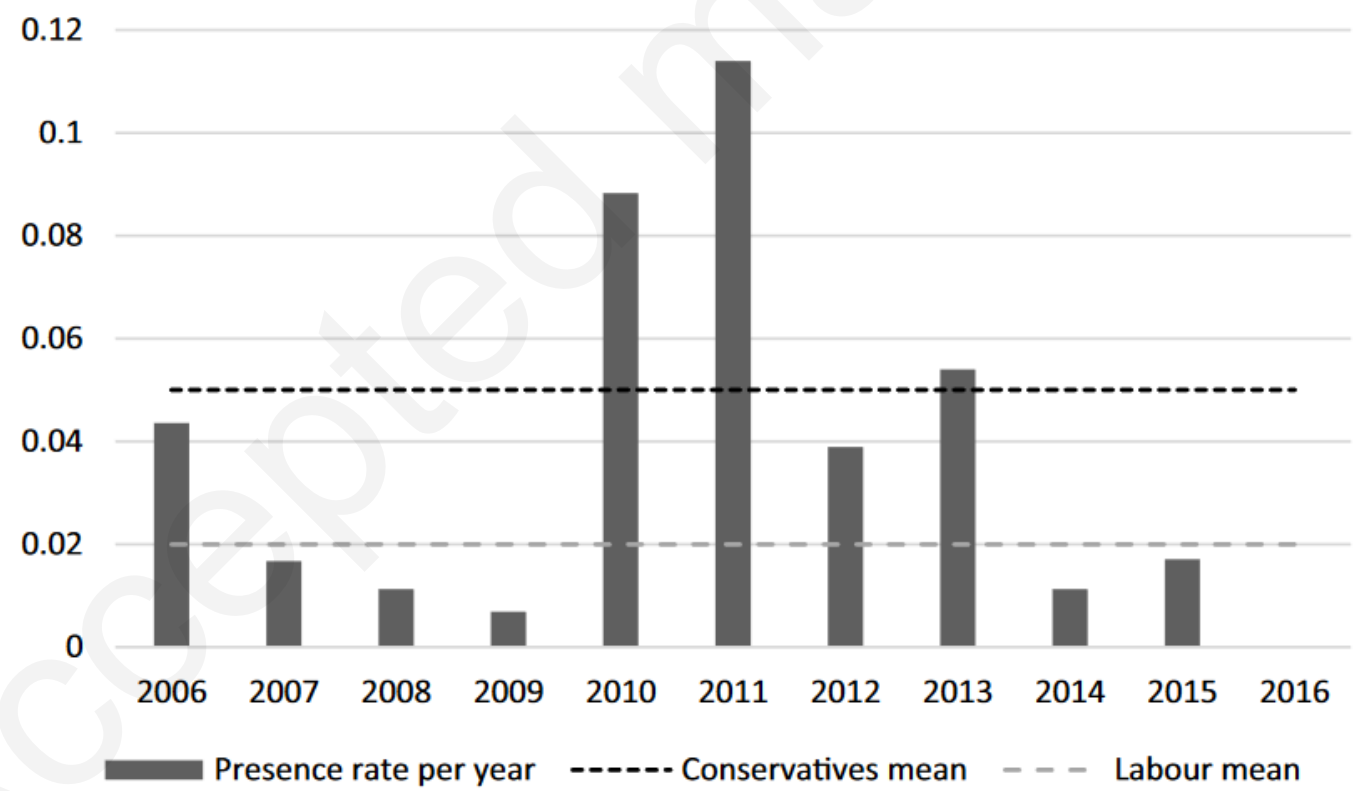

Fig. 5 Presence rate of the expression 'value for money' in speeches by the Secretary of State for Defence and Minister for Defence Procurement per year 
UK Military Expenditure between 2006 and 2016 (in billions of constant $2015 £$ )

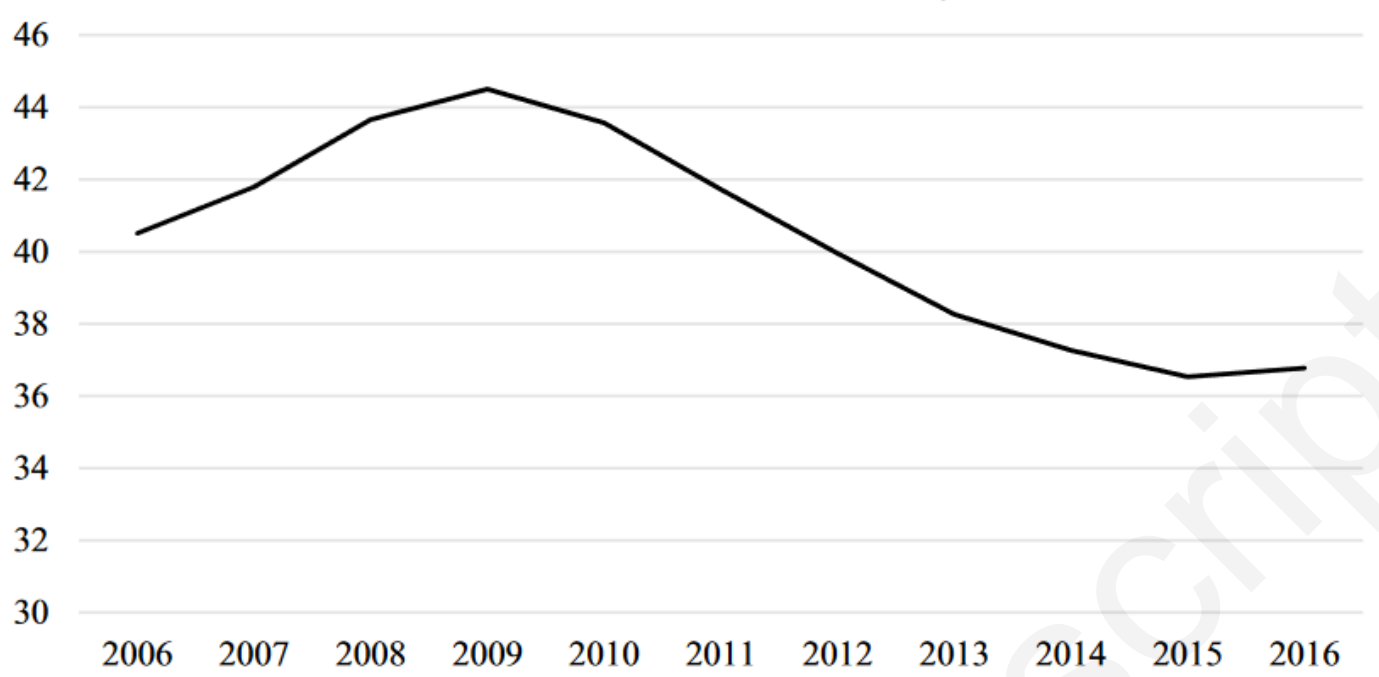

Fig. 6 UK military expenditure between 2006 and 2016 (in billions of constant 2015£. Source SIPRI) 